\title{
Influencia de las condiciones de almacenamiento sobre la relajación de aceros de pretensado
}

\section{Influence of the storage conditions on prestressing steel relaxation losses}

\author{
F. Suárez ${ }^{(*)}, \underline{\text { J. C. Gálvez }}^{(*)}$, J. M. Atienza(*), D. A. Cendón ${ }^{(*)}$ y M. Elices(*)
}

Recepción/Received: 19-VII-11

Aceptación/Accepted: 22-XI-11

Publicado online/Online publishing: 31-VII-12

\section{RESUMEN}

La pérdida de tensión por relajación en las armaduras activas afecta de forma importante a las estructuras de hormigón pretensado. Por ello se realizan ensayos de relajación de los alambres y cordones de pretensado tras su fabricación. Después, el material es enrollado y almacenado durante periodos que en ocasiones pueden superar el año de duración. Generalmente se desprecia la influencia que estas operaciones posteriores a la fabricación pueden tener sobre el material. Sin embargo, diversos fabricantes y suministradores han constatado experimentalmente que, en ocasiones, el material almacenado durante un periodo prolongado presenta pérdidas de relajación mayores que inmediatamente tras su fabricación. En este trabajo se realizan ensayos de laboratorio para comprobar la influencia que el radio de enrollamiento y el periodo de almacenamiento tienen sobre las pérdidas de relajación. También se propone un modelo analítico que permite predecir de manera razonablemente aproximada el valor del ensayo de relajación sobre un alambre sometido a un enrollamiento prolongado. Este modelo explica la evolución del perfil de tensiones durante el proceso de enrollamiento-almacenamiento-desenrollamiento, así como la influencia de las tensiones residuales.

Palabras clave: acero, pérdidas por relajación, enrollamiento, almacenamiento.

\section{SUMMARY}

Stress relaxation losses on active reinforcement have significant impact on prestressed concrete structures. This is why relaxation tests are carried out on prestressing steel wires and strands after being manufactured. Then, these materials are coiled and stored for a long-term period, sometimes in excess of one year. The influence of these operations, carried out after manufacturing, is usually neglected. Nevertheless, some manufacturers and contractors have noticed that, sometimes, when relaxation tests are carried out after a long-term storage, the relaxation losses found are higher than those measured immediately after manufacturing. In this work, lab tests are performed to check the influence of the coiling radius and the period of storage on the relaxation test. In addition to this, an analytical model is presented to predict the results of a relaxation test carried out on a wire coiled and stored for a longterm period. This model explains the evolution on the cross-sectional stress profile along the coiling-storinguncoiling process, as well as the influence of the residual stresses on it.

Keywords: steel, relaxation losses, coiling, storage.

(*) Universidad Politécnica de Madrid (Madrid, España). 


\section{INTRODUCCIÓN}

En los elementos de hormigón pretensado la pérdida de tensión por relajación de las armaduras activas juega un papel fundamental, ya que puede reducir la carga de compresión del hormigón y, por tanto, afectar a la seguridad de la estructura. Por este motivo, las normas imponen unos límites muy estrictos para mantener dichas pérdidas dentro de la seguridad. Las pérdidas por relajación se miden mediante unos ensayos estandarizados (ISO 15630-3 (1), ASTM E328-86 (2)), cuyos resultados deben ser aportados por el fabricante para la aceptación de las armaduras. Los alambres que tienen unas pérdidas inferiores al 2,5\% de la tensión inicial (después de 1.000 horas, cuando se someten a una carga inicial del $70 \%$ de su resistencia a tracción) se llaman alambres de baja relajación y son los recomendados en la actualidad (3).

Dada la importancia del fenómeno de la relajación, se han realizado numerosos trabajos que tratan de explicar la influencia de diversos aspectos del procesado de los alambres en su comportamiento final a relajación (4-9). Estos estudios se han centrado especialmente en la influencia de la temperatura y de las tensiones residuales generadas durante el proceso de trefilado o en el efecto del tratamiento de estabilizado que se le da al material al finalizar su procesado. Sin embargo, no se ha prestado atención a la etapa que viene a continuación, y es previa a la puesta en obra: el enrollado y almacenamiento del material.

Diversos fabricantes y suministradores de alambres y cordones de acero para pretensar han constatado experimentalmente que en algunos casos este acero, cuando se enrolla para su almacenamiento durante cierto periodo de tiempo, empeora su comportamiento a relajación. El deterioro es más acusado cuanto menor es el diámetro de enrollado y más prolongado el tiempo de almacenamiento, especialmente si éste se realiza con temperaturas elevadas (10). En opinión de los autores, este fenómeno es causado por la relajación de las tensiones a las que se ve sometido el alambre como consecuencia del enrollado y que, una vez desenrollado, induce un perfil de tensiones residuales que se manifiesta en una curvatura permanente que no existía previamente. La Figura 1 muestra de forma esquemática este fenómeno.

Con el fin de limitar este fenómeno, las normas y recomendaciones $(3,11)$ limitan el diámetro interior de los rollos de alambre y cordón para su transporte y almacenaje. En el artículo 70 de la EHE-08 (3) se recogen los valores de estos límites. Esta limitación persigue que durante el proceso de enrollado no se alcancen tensiones elevadas en alguna de las fibras del alambre o cordón. Sin embargo, aunque los valores de las tensiones alcanzadas están lejos de los de plastificación, en ocasiones

\section{INTRODUCTION}

Relaxation stress loss of active reinforcement is of significant importance in prestressed concrete structures, given that it can lead to a reduction in the compressive strength of concrete and, therefore, affect structural safety. This is the reason why these losses are strictly limited by the standards. Relaxation losses are measured by means of standardised tests - ISO 15630-3 (1), ASTM E328-86 (2) - and the results of these tests must be provided by the manufacturer so that reinforcement can be checked for acceptance. The steel wires that present losses below $2.5 \%$ of the initial stress (after 1000 hours and under an initial load of $70 \%$ of the tension strength) are classified as low relaxation wires and are at present recommended (3).

Given the importance of such a phenomenon, many studies have been carried out to explain the influence of several aspects of the steel manufacturing process on its final relaxation behaviour (4-9). These studies have been focused especially on the influence of temperature, on the stresses caused by cold-drawing and on the stabilising treatment applied at the end of the manufacturing process. However, attention has not been given to the stage that follows it, which is prior to the transportation of the material to the workplace: coiling and storage.

Some prestressing steel wire manufacturers and suppliers have observed experimentally how long-term storage increases the material relaxation losses. The smaller the coiling radius and the longer the storage period, the more accentuated this effect is, especially with high temperatures (10). In the authors' opinion, this is due to the relaxation losses induced in the wire when it is coiled, which are responsible for the final curvature observed after uncoiling (Figure 1).

In order to limit the influence of coiling on the relaxation behaviour of the material, standards $(3,11)$ give limitations for the inner diameter of coils used for transport and storage. These limits can be consulted in Article 70 of the Spanish standard EHE-08 (3). This limitation is intended to avoid the appearance of excessive stresses on the cross section of the wire. In fact, they are given to keep the whole section working elastically. Nevertheless, even below the elastic limit, 


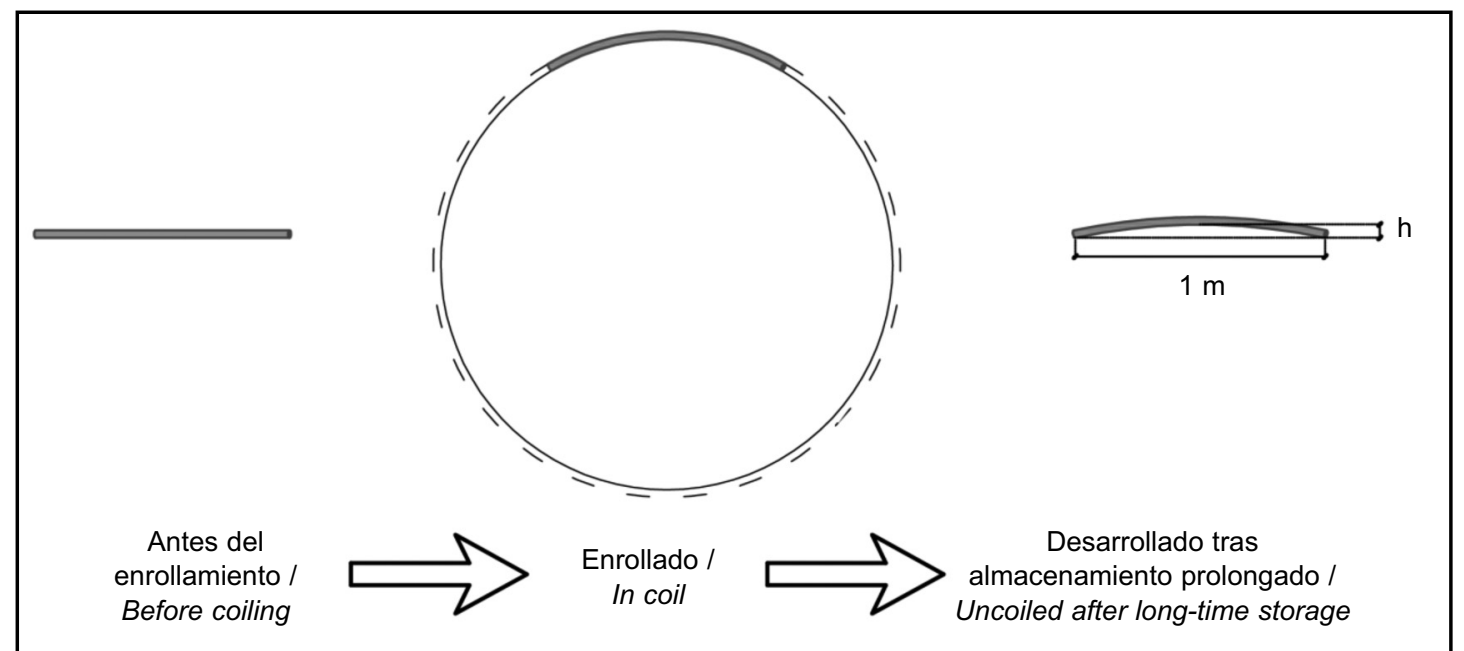

Figura 1. Croquis del efecto que el proceso de enrollamiento-desenrollamiento tiene sobre el alambre tras un largo periodo de almacenamiento.

Figure 1. Sketch of the effect of the coiling-uncoiling process on a wire stored for a long-term period.

son suficientes para que se produzca una relajación local en las fibras más tensionadas que, una vez desenrollado el alambre, originan un perfil de tensiones residuales causante del fenómeno señalado.

Se trata de un fenómeno no suficientemente estudiado que puede verse acentuado, entre otros factores, por las tensiones residuales que pueda tener el material antes de enrollarlo. De forma práctica, algunas normas (3) limitan la flecha admisible a $25 \mathrm{~mm}$ en alambres y $20 \mathrm{~mm}$ en cordones en una base de medida de $1 \mathrm{~m}$, al dejarlos sobre una superficie plana (Figura 1).

A pesar de las precauciones indicadas, se ha comprobado experimentalmente que alambres y cordones comerciales, procedentes de varios suministradores, y que han estado almacenados enrollados durante un largo periodo de tiempo, a veces superior a un año, presentan pérdidas por relajación mayores que las esperadas. Cuando estos alambres son desenrollados y sometidos al ensayo de relajación, las pérdidas resultantes son significativamente superiores a las obtenidas antes del enrollamiento, conduciendo al rechazo del material en alguno de los casos.

No se dispone de una investigación que permita entender y cuantificar los mecanismos involucrados en este fenómeno, ni la relación entre ellos. Este artículo estudia cómo influye el proceso de enrollamiento y almacenamiento de los alambres de acero trefilado en las pérdidas por relajación una vez desenrollado. Con este fin se ha desarrollado una campaña experimental con alambre trefilado comercial de $7 \mathrm{~mm}$ de diámetro, enrollado con tres radios internos distintos, en la que se comparan los valores de la relajación del alambre antes del enrollamiento (recto) y los valores de la relajación tras el enrollamiento (curvo). Los ensayos de relajación se realizaron these stresses can be sufficient for a local relaxation process to take place, which be responsible for the final curvature observed after uncoiling.

This involves a little-studied phenomenon that can be accentuated, among other reasons, by the residual stresses developed in the material before coiling. As a practical check of this effect, some standards (3) give a limitation for the sagitta on a 1m-long wire after uncoiling, with it being smaller than $25 \mathrm{~mm}$ for wires and $20 \mathrm{~mm}$ for strands (Figure 1).

Despite the aforementioned limitations and recommendations, experimental cases have been found where wires obtained from different manufacturers and coiled and stored for long-term periods, on occasions for longer than one year, have presented higher relaxation losses than those obtained before storage. When these wires are uncoiled, the relaxation losses obtained with a relaxation test are significantly higher than those obtained before coiling and, in some cases, give rise to rejection of the material.

There is no specific research available to understand and quantify either the mechanisms involved in this phenomenon or how they interact with each other. In this paper, the effect of coiling and long-term storage on the relaxation losses is studied. To assess these factors, an experimental programme is developed with 7- $\mathrm{mm}$ diameter commercial cold-drawn steel wires using three inner coiling diameters, comparing the relaxation losses before coiling with the relaxation losses after coiling. For the relaxation tests, two stress ratios are considered, one at $70 \%$ of the ultimate tensile strength (uts) and another at $80 \%$ of the uts. The results obtained with these tests 
al $70 \%$ y al $80 \%$ de la tensión máxima real del material, y ponen de manifiesto la influencia que el proceso y el tiempo de enrollado puede tener en la relajación del material.

Además, se propone un modelo analítico en el que, a partir de las tensiones residuales iniciales (estimadas o medidas experimentalmente), se reproducen los distintos estados tensionales por los que pasa la sección transversal del alambre: enrollamiento, relajación de tensiones durante el almacenamiento y posterior desenrollamiento. Con el estado final de tensiones en la sección transversal del alambre después de este proceso, el modelo reproduce también el ensayo de relajación. Los resultados se comparan con los obtenidos experimentalmente, obteniéndose un buen ajuste. El modelo permite entender algunos aspectos cruciales del proceso, como la evolución de las tensiones en la sección transversal del alambre a lo largo del tiempo a consecuencia del doblado y la relajación. Por otro lado, facilita la extrapolación de resultados a otros radios de doblado y tiempos de almacenamiento.

\section{CAMPAÑA EXPERIMENTAL}

\subsection{Material de partida: alambre recto}

El material empleado fue alambre de acero eutectoide comercial obtenido por trefilado en frío. Su composición química era: 0,815\% C, 0,231\% Si, 0,642\% Mn, 0,012\% $\mathrm{P}, 0,008 \% \mathrm{~S}, 0,044 \% \mathrm{~V}$ y $0,221 \% \mathrm{Cr}$, en porcentaje de peso. El diámetro del alambre era de $7 \mathrm{~mm}$, obtenido a partir de alambrón de $12 \mathrm{~mm}$ de diámetro mediante un proceso de trefilado durante el cual el alambre atravesó seis matrices consecutivas de diámetros cada vez menores hasta alcanzar el diámetro deseado de $7 \mathrm{~mm}$ (Figura 2). La velocidad de trefilado fue $44 \mathrm{~m} / \mathrm{s}$ y la temperatura, que fue controlada durante el proceso, alcanzó un valor máximo de $197^{\circ} \mathrm{C}$ en la superficie del alambre al finalizar el último estiramiento. Tras el trefilado, los alambres fueron sometidos a un tratamiento termo-mecánico industrial (estabilizado) para eliminar las tensiones residuales generadas durante el procesado en frío.

El alambre fue suministrado en barras rectas obtenidas tras el proceso de estabilizado y antes de ser enrollado para su almacenamiento. La Figura 3 muestra el diagrama tensión-deformación obtenido experimentalmente. Este ensayo se realizó con una probeta de $200 \mathrm{~mm}$ de longitud, a una velocidad de alargamiento de $3 \mathrm{~mm} / \mathrm{min}$, medida con un extensómetro resistivo sobre una base de medida de $12,5 \mathrm{~mm}$, en una máquina universal de ensayos con una célula de carga de 100 kN.

Además, se midieron las tensiones residuales en la superficie del alambre mediante difracción de rayos $\mathrm{X}$ y las show how the coiling process and the time of storage affect the final relaxation behaviour of the material.

In addition to these tests, an analytical model is developed to model the effect of coiling on the material behaviour. Using the initial residual stresses of the material (estimated or measured experimentally) as input, the model reproduces the stress and strain profiles for the stages that take place through the coiling-storinguncoiling process. Using the stress profile that emerges from this process, the model also calculates the relaxation losses obtained with a relaxation test. The results are compared with those obtained experimentally and show good agreement with them. This model allows understanding of some important aspects of the process, as the evolution of the stress profile in the cross section of the wire through the coiling-storing-uncoiling process due to the relaxation losses that take place. On another point, it allows extrapolation of the experimental data to obtain results for other coiling diameters and storage periods.

\section{EXPERIMENTAL WORK}

\subsection{Material properties: straight wire}

For this research, wires manufactured by cold-drawn eutectoid steel rods are used. The chemical composition is: $0.815 \% \mathrm{C}, 0.231 \% \mathrm{Si}, 0.642 \% \mathrm{Mn}, 0.012 \% \mathrm{P}$, $0.008 \% S, 0.044 \% V$ and $0.221 \% \mathrm{Cr}$, in weight percentage. The diameter of the wire is $7 \mathrm{~mm}$, obtained by cold-drawing from a $12 \mathrm{~mm}$ wire and after six drawing passes applied at a speed of $44 \mathrm{~m} / \mathrm{s}$ and at a temperature, monitored during the process, that reaches a maximum value of $197{ }^{\circ} \mathrm{C}$ on the wire surface at the last pass. After cold-drawing, an industrial thermomechanical treatment is applied (stabilising) to relieve the residual stresses induced during the process.

The $7 \mathrm{~mm}$ wire is supplied in the form of straight bars obtained after the stabilising process and before they are coiled for storage. Figure 3 shows the stress-strain diagram obtained experimentally. This test is carried out with a $200 \mathrm{~mm}$-long specimen at an elongation rate of 3 $\mathrm{mm} / \mathrm{min}$, measured with an extensometer base of 12.5 $\mathrm{mm}$ and using a universal test machine with a load cell of $100 \mathrm{kN}$.

Moreover, the residual stresses on the wire surface are measured by means of $X$-ray diffraction and the residual 


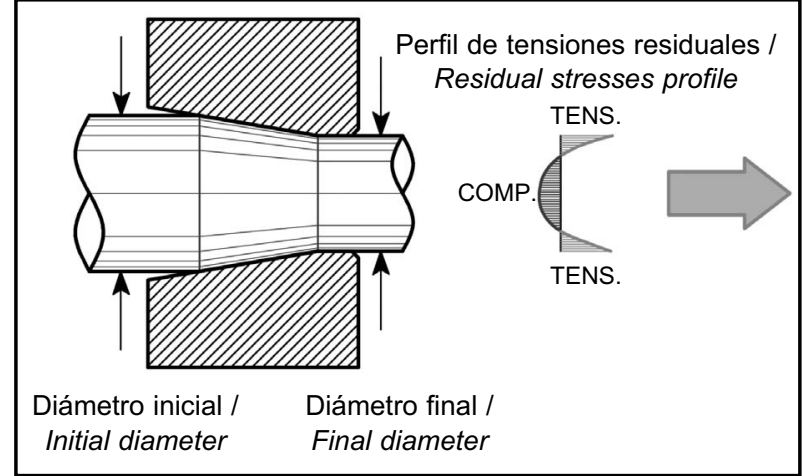

Figura 2. Esquema del proceso de trefilado y de las tensiones residuales generadas.

Figure 2. Sketch of a cold-drawn process and the resulting residual stresses.

tensiones residuales en el interior del alambre mediante difracción de neutrones. La Figura 4a muestra la distribución de tensiones residuales en la superficie del alambre y la Figura 4b la distribución de tensiones residuales en el interior del alambre (12). Los detalles sobre la aplicación de estas técnicas se pueden consultar en las ref. $(13,14)$.

Asimismo, se realizó el ensayo para la medida de la relajación de tensiones al $70 \%$ y $80 \%$ de la tensión real de rotura. Como se explica más adelante, los resultados de estos ensayos sirvieron de base para estimar el comportamiento del material en ensayos de relajación bajo diferentes cargas iniciales, dato necesario en el modelo analítico desarrollado en este trabajo.

\subsection{Material ensayado: alambre curvo}

Para estudiar la influencia del enrollamiento en el resultado del ensayo de relajación, se adoptaron tres diámetros de doblado para los alambres. La normativa (3)

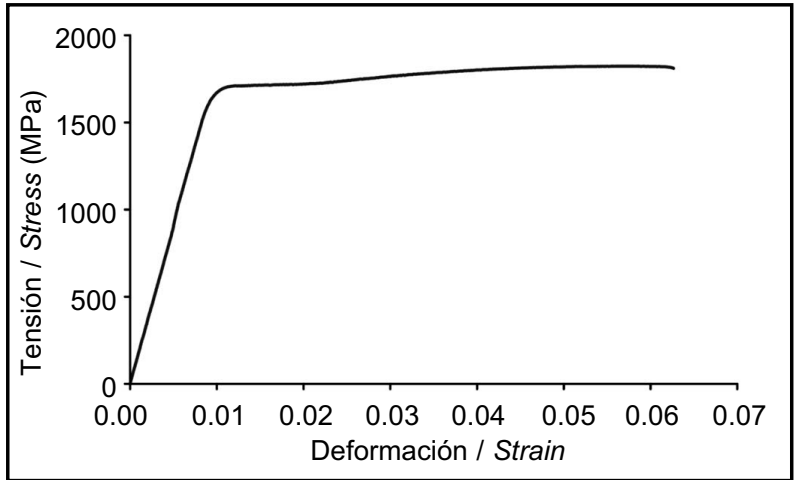

Figura 3. Curva tension-deformación del alambre empleado en los ensayos.

Figure 3. Stress-strain diagram of the material tested.

stresses along a diameter are obtained by neutron diffraction. Figure $4 a$ shows the residual stresses distribution on the wire surface and Figure $4 b$ the residual stresses inside the wire (12). More information on these techniques may be consulted in references (13, 14).

In addition to this, relaxation tests at $70 \%$ and $80 \%$ of the real tensile strength are carried out. As it will be explained later, these results are needed to estimate the material behaviour under relaxation tests at different initial loadings, which is one of the input data used by the analytical model that will be described later.

\subsection{Tested material: curved wire}

To study the influence of coiling on the relaxation test results, three coiling diameters are considered. The Spanish standard (3) recommends a minimum coiling

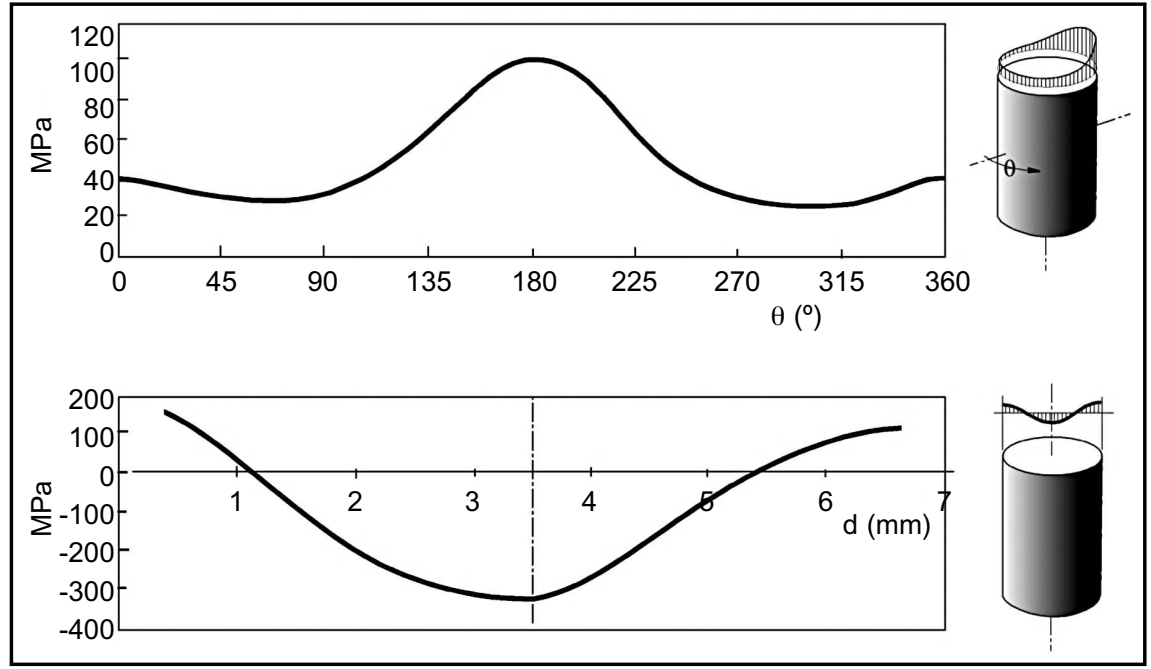

Figura 4. Tensiones residuales medidas en el alambre empleado en los ensayos: a) en el perímetro, b) a lo largo de un diámetro. Figure 4. Residual stresses measured on the tested wire: a) around the perimeter, b) along a diameter. 
establece como diámetro mínimo de enrollado un valor de 225 veces el diámetro del alambre, que en este caso corresponde a $1.575 \mathrm{~mm}$. Los diámetros adoptados en este estudio fueron tales que, una vez liberado el alambre, tras permanecer enrollado 120 horas, se midieron unos valores de diámetros remanentes de $D=500 \mathrm{~mm}$, $\mathrm{D}=1.000 \mathrm{~mm}$ y $\mathrm{D}=9.000 \mathrm{~mm}$.

Los dos diámetros menores, que no cumplen con las especificaciones de la normativa (3), fueron estudiados con el fin de comprobar la influencia del enrollamiento con diámetros muy pequeños. El diámetro mayor, $\mathrm{D}=9.000 \mathrm{~mm}$, cumple con las especificaciones de doblado establecidas en la normativa (3). En el caso particular de este alambre, la limitación de la flecha a $25 \mathrm{~mm}$ en una longitud de $1 \mathrm{~m}$ conduce a un diámetro tras el desenrollamiento de $9.500 \mathrm{~mm}$, muy próximo al valor estudiado.

\subsection{Ensayos de relajación sobre los alambres sometidos a enrollamiento prolongado}

Se han realizado ensayos de tracción y relajación de las probetas curvadas. Los ensayos de tracción se han realizado de la misma forma descrita en el apartado 2.1 para las probetas sin curvar.

Los ensayos de relajación se realizaron con dos probetas para cada diámetro de enrollamiento. Al igual que en el caso del ensayo de tracción, las probetas fueron ensayadas sin haber sido enderezadas previamente, es decir, con la curvatura resultante tras el desenrollamiento del alambre. Estos ensayos se realizaron de acuerdo a la diameter of 225 times the wire diameter that, in this case, corresponds to $1575 \mathrm{~mm}$. The diameters used in this study are such that, once the wire is uncoiled after 120 hours in coil, remaining diameters are $D=500 \mathrm{~mm}$, $D=1000 \mathrm{~mm}$ and $D=9000 \mathrm{~mm}$.

The two smaller diameters do not comply with the standard (3), and are studied in order to check the influence of very small coiling diameters. The largest diameter complies with the coiling specifications required by the standard (3). In the particular case of the wire used in this study, the sagitta on a $1 \mathrm{~m}$ long wire after uncoiling, which is limited by the standard (3) with a maximum value of $25 \mathrm{~mm}$, corresponds to an uncoiled diameter of $9500 \mathrm{~mm}$, very close to the real diameter.

\subsection{Relaxation tests on wires coiled and stored for a long-term period}

Tension and relaxation tests are carried out with curved wire specimens, that is to say, with specimens that show a remaining curvature due to the long-term storage in coil. These tests are performed as described in section 2.1 for straight specimens.

Relaxation tests are carried out on two specimens for each coiling diameter. As in the tension tests, the specimens are tested without previous straightening, with the resulting curvature after uncoiling. These tests are performed according to ASTM E328-86 (2), measuring the stress loss over time under constant

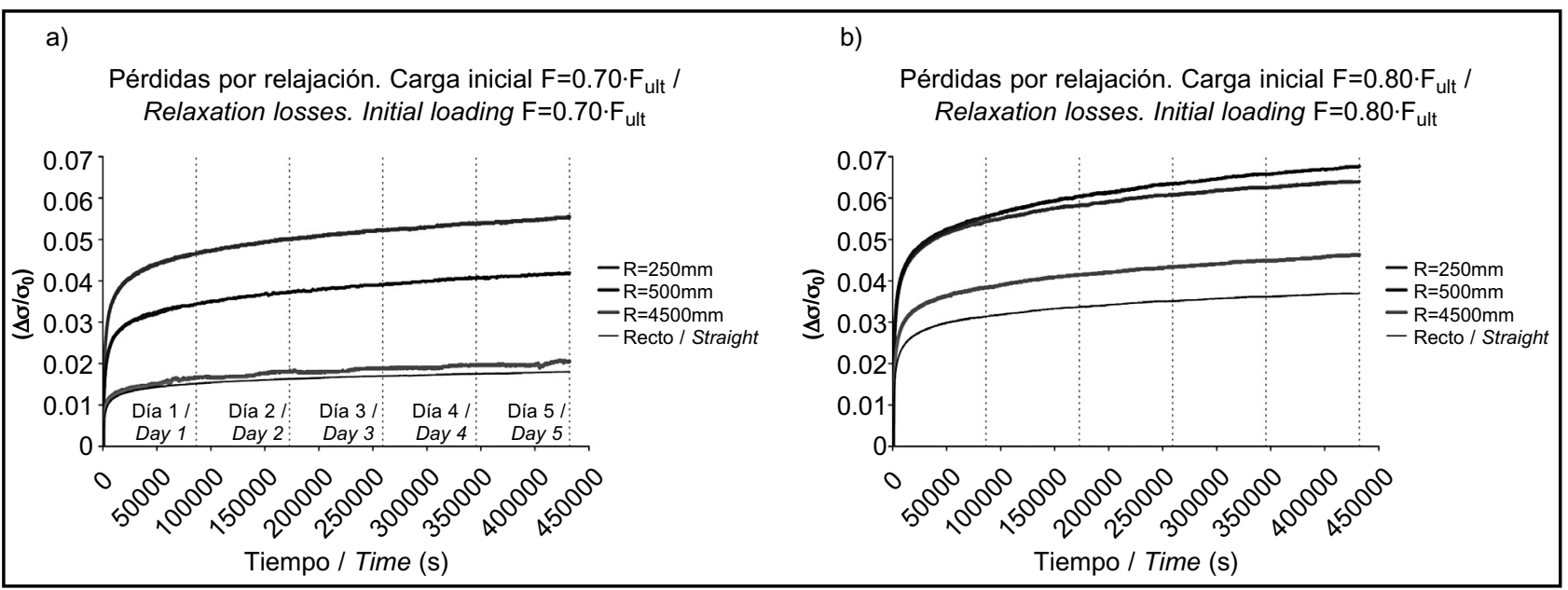

Figura 5. Evolución de las pérdidas por relajación en un ensayo a $120 \mathrm{~h}$ para cada uno de los radios de enrollamiento considerados: a) ensayos al $70 \%$ de la carga de rotura, b) ensayos al $80 \%$ de la carga de rotura.

Figure 5. Development of relaxation losses in a $120 \mathrm{~h}$ relaxation test for each of the coiling diameters considered: a) tests at $70 \%$ of the ultimate tensile strength, b) tests at $80 \%$ of the ultimate tensile strength. 
norma ASTM E328-86 (2), midiendo la pérdida de tensión a lo largo del tiempo, bajo deformación constante. Se realizaron dos tipos de ensayos para cada una de las curvaturas, uno bajo carga inicial del $70 \%$ de la tensión de rotura y otro bajo carga inicial del $80 \%$ de la tensión de rotura. Cada ensayo tuvo una duración de 120 horas y la evolución de la carga fue medida de manera continua con una célula de carga.

La Figura 5 muestra la relajación como pérdida porcentual de tensión a lo largo de cada ensayo para las probetas con los tres radios de doblado. Las curvas corresponden al valor medio de los resultados de dos probetas ensayadas en iguales condiciones.

\section{MODELO ANALÍTICO PARA EL ESTUDIO DEL EFECTO DEL ENROLLAMIENTO}

El modelo que a continuación se presenta calcula la distribución de tensiones y deformaciones en la sección transversal del alambre durante el proceso de enrollamiento y desenrollamiento. Debido a que dicho proceso puede provocar en algunas fibras secuencias de carga y descarga, es conveniente destacar que este modelo tiene en cuenta el efecto Bauschinger que pueden sufrir algunas fibras de la sección transversal durante el proceso de enrollamiento y desenrollamiento.

En primer lugar, a continuación se detallan los datos de partida que es necesario introducir en el modelo. En segundo lugar, se describe el proceso de cálculo que lleva a cabo éste y que está ligado a los diferentes perfiles de tensiones que aparecen en el alambre como consecuencia de cada una de las operaciones que tienen lugar durante todo el proceso. Finalmente se muestran los resultados obtenidos en el caso de los alambres ensayados experimentalmente.

\subsection{Datos de entrada del modelo}

Este modelo calcula las pérdidas de relajación en un ensayo a $120 \mathrm{~h}$ para un alambre que ha sido sometido a enrollamiento prolongado. Para ello, el modelo precisa de los siguientes datos de partida:

- Diámetro del alambre.

- Diámetro de enrollamiento.

- Curva tensión-deformación del alambre.

- Perfil de tensiones residuales inicial.

- Comportamiento del alambre recto y sin tensiones residuales iniciales en un ensayo de relajación con diferentes cargas iniciales. strain. Two tests are carried out for each curvature, one under an initial loading of $70 \%$ uts and another one under an initial loading of $80 \%$ uts. All these tests have a duration of $120 \mathrm{~h}$ and the load evolution is measured continuously with a load cell.

Figure 5 shows the effect of relaxation as a percentage loss of stress through each test for the specimens of each of the three coiling radii. These curves show the average value of two specimens tested under the same conditions.

\section{AN ANALYTICAL MODEL FOR ASSESSING THE EFFECT OF COILING}

The analytical model presented here is used to reproduce the evolution of the stress profile on the cross-section of the wire during the coiling-storing-uncoiling process and to predict the influence of this procedure on the relaxation test. Given that this process can lead some fibres in the cross-section to experiment loading-unloading sequences, this model takes into account the Bauschinger effect that can take place in some parts of the cross-section throughout the coiling-uncoiling process.

In the first place, the input data required by the model are described. In the second place, the calculation process is described, defining the evolution of the stress profile along the coiling-storing-uncoiling process and the eventual relaxation test. Finally, the results obtained are presented and compared with the experimental ones.

\subsection{Input data}

This model predicts the relaxation stress losses in a $120 \mathrm{~h}$ test for a wire that has been subjected to prolonged coiling. To this end, the model requires the following input data:

- Wire diameter.

- Coiling diameter.

- Stress-strain curve of the wire.

- Profile of the initial residual stresses.

- Behaviour of the straight wire, without initial residual stresses, under a relaxation test with different initial loadings. 


\subsection{Evolución del perfil de tensiones introducido por el proceso de enrollamiento- desenrollamiento del alambre}

Este modelo se basa en el cálculo del perfil de tensiones en una de las secciones del alambre para cada una de las fases por las que atraviesa el mismo durante el proceso de enrollado y desenrollado. Para estos cálculos a nivel de sección, se adopta la hipótesis de Navier, según la cual las secciones planas antes de la deformación siguen siendo planas después de la deformación.

La Figura 6 resume las fases calculadas en el modelo analítico y muestra el perfil de tensiones en la sección transversal del alambre durante cada una de ellas:

- Perfil 0. Estado inicial: no hay tensiones en el alambre.

- Perfil 1. Enrollamiento del alambre: al enrollar el alambre se introduce un momento flector externo que genera un perfil lineal de tensiones.

- Perfil 2. Después de un enrollamiento prolongado: el perfil de tensiones experimenta una cierta relajación de acuerdo con la Figura 7. De esta manera, las pérdidas por relajación no son iguales en toda la sección, siendo mayores en las fibras extremas, que soportan un estado tensional mayor.

- Perfil 3. Desenrollamiento: el perfil final de tensiones resulta de aplicar sobre la sección el momento flector necesario para equilibrar las tensiones resultantes del perfil 2 con el signo inverso. A pesar de que las tensiones están autoequilibradas, las fibras no presentan un estado de tensiones igual al que presentaban antes del enrollamiento. Esto es debido a que, como se ha mencionado, la relajación no es igual en toda la

\subsection{Stress profile evolution along the coiling-storing-uncoiling process}

This model is based on calculating the stress profile in a cross-section of the wire for each of the stages that take place during the coiling-storing-uncoiling process. For such calculations, Navier hypothesis is adopted which states that plane sections before loading remain plane after loading.

Figure 6 summarises the stages considered by the analytical model and show the stress profile in a crosssection of the wire for each of them:

- Profile 0. Initial state: No stresses.

- Profile 1. After coiling: The wire is curved due to the application of a bending moment, which generates a linear stress profile.

- Profile 2. After some time in coil: Tensile stresses relax according to Figure 7. Therefore, relaxation losses are different across the section, and higher in the outer fibres given that they are under higher stresses.

- Profile 3. After uncoiling: The stress profile is obtained by subtracting the above mentioned external moment to balance the corresponding loads. It should be noted that some stresses remain although the whole stress profile is self-balanced.

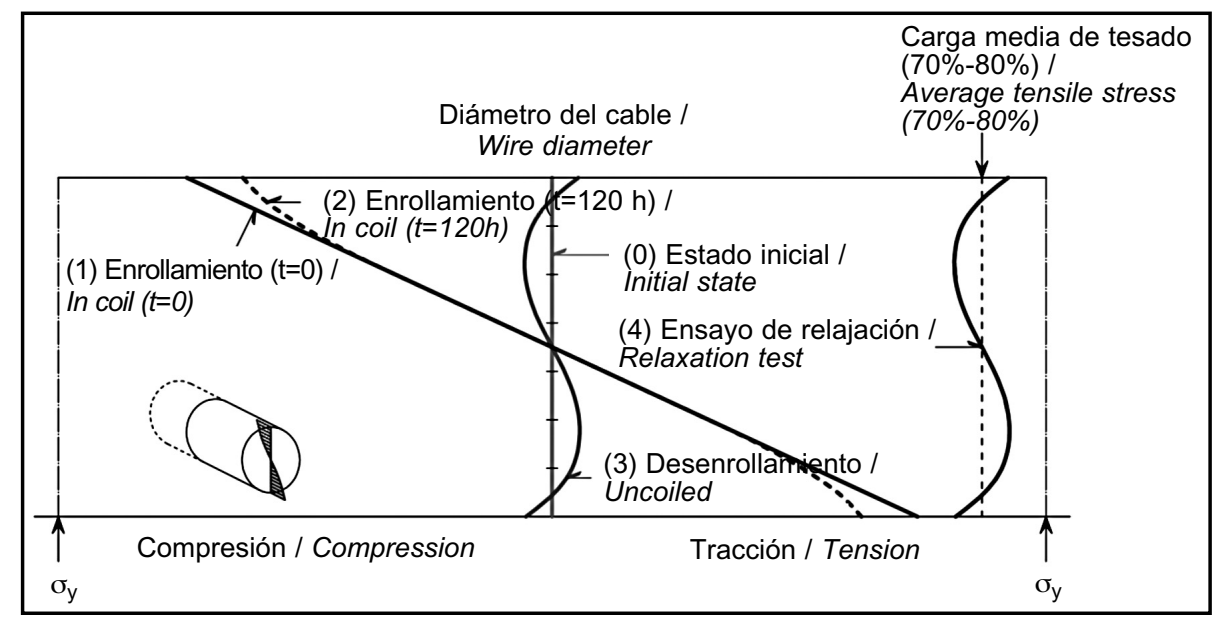

Figura 6. Perfiles de tensiones en la sección transversal de un cable sin tensiones residuales durante el proceso de enrollamiento-desenrollamiento: (0) antes del enrollamiento, (1) recién enrollado, (2) tras $120 \mathrm{~h}$ enrollado, (3) una vez desenrollado, (4) una vez aplicada la carga del ensayo de relajación.

Figure 6. Stress profiles during the coiling-uncoiling process for a wire without initial residual stresses: (0) before coiling, (1) just coiled, (2) after $120 \mathrm{~h}$ coiled, (3) once uncoiled, (4) under the relaxation test load. 


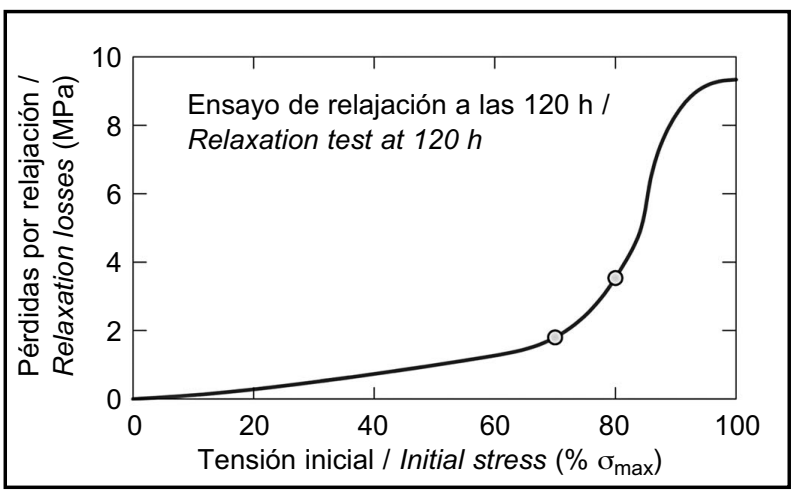

Figura 7. Comportamiento del alambre en un ensayo de relajación frente a diferentes cargas iniciales. Figure 7. Behaviour of a wire tested in a relaxation test under different initial loads.

sección durante el tiempo que el alambre permanece enrollado. De esta manera, aunque al principio el alambre no tenga tensiones residuales iniciales, éstas pueden aparecer tras el proceso de enrollamientodesenrollamiento.

- Perfil 4. Ensayo de relajación: se endereza el alambre (al realizar el ensayo, la propia aplicación de la carga provoca el enderezado) y se aplica la fuerza correspondiente al ensayo de relajación. En la Figura 6, correspondiente a un hipotético alambre sin tensiones residuales iniciales, se observa cómo, debido al proceso de enrollamiento-desenrollamiento y al perfil de tensiones residuales que induce, no toda la sección está sometida al mismo estado tensional durante el ensayo. Las pérdidas por relajación del alambre resultan de sumar las pérdidas producidas en toda la sección. En el ejemplo mostrado en la Figura 6 el alambre se ensaya al $70 \%$ de la tensión de rotura. Nótese en este ejemplo que algunas fibras presentan tensiones superiores al $70 \%$ y, por tanto, experimentarán pérdidas mayores que las esperadas, mientras que otras fibras presentan tensiones inferiores al $70 \% \mathrm{y}$, por tanto, experimentarán pérdidas menores que las esperadas. Sin embargo, tal y como muestra la Figura 7, la relajación de tensión no crece de forma lineal con la tensión aplicada, siendo más importantes los incrementos que los descensos de tensión. De este modo, en general, un alambre sometido al ensayo de relajación antes del enrollamiento sufrirá menores pérdidas de tensión que después del proceso de enrollamiento-desenrollamiento.

En el caso de que el alambre tenga tensiones residuales al inicio del proceso (véase Figura 4), éstas se incorporan en el perfil inicial de tensiones (perfil 0), que en este caso no sería un perfil de tensiones nulas.

La Figura 8 es análoga a la Figura 6, pero con una distribución inicial de tensiones residuales. En este caso la distribución de tensiones en la sección transversal puede perder su carácter lineal.
This is because the stress relaxation occurs in an inhomogeneous form throughout the cross section.

- Profile 4. Relaxation test: The wire is straightened (when the wire is tested, the loading of the wire causes it to remain straight during the test) and the corresponding initial loading is applied. Figure 6 corresponds to an ideal wire without initial residual stresses; it shows how as a consequence of the coiling-storing-uncoiling process, not the whole section is under the same stress ratio during the test. The relaxation losses of the wire are the sum of the losses produced throughout the whole section. Figure 6 shows an example where the wire is tested at 0.70 uts. It is to be noted that some fibres are more loaded than 0.70 uts and, hence, higher stress losses should be expected. Also, some fibres are less loaded than 0.70 uts but, as shown in Figure 7, stress relaxation losses do not increase linearly and increases are more critical than decreases. The overall behaviour is that after the coiling-storinguncoiling process, the wire exhibits relaxation losses higher than those of the wire before coiling.

If the wire presents initial residual stresses (see Figure 4), these are added in the initial stress profile (profile 0 ), which would not be a profile without stresses anymore.

Figure 8 is similar to Figure 6, though it corresponds to a wire with an initial residual stress distribution. In this case, some stress profiles in the cross section may lose their linearity. 


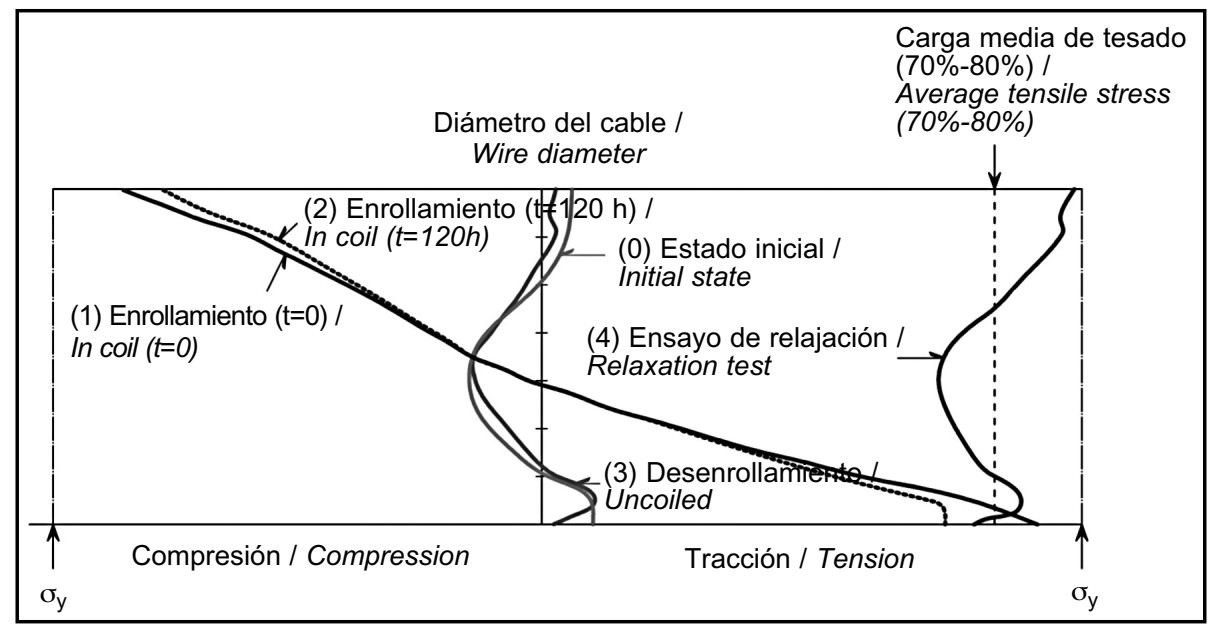

Figura 8. Perfiles de tensiones en la sección transversal de un cable con tensiones residuales durante el proceso de enrollamientodesenrollamiento: (0) antes del enrollamiento, (1) recién enrollado, (2) tras 120 h enrollado, (3) una vez desenrollado, (4) una vez aplicada la carga del ensayo de relajación.

Figure 8. Stress profiles during the coiling-uncoiling process for a wire with initial residual stresses: (0) before coiling, (1) just coiled,

(2) after $120 \mathrm{~h}$ coiled, (3) once uncoiled, (4) under the relaxation test load.

\subsection{Predicción de las pérdidas de relajación de los alambres sometidos a enrollamiento prolongado}

El modelo arriba descrito se ha empleado para predecir la relajación de los alambres enrollados. Para el cálculo se ha empleado la curva tensión-deformación (Figura 3) obtenida experimentalmente y las tensiones residuales medidas en el perímetro del alambre y en un diámetro del mismo, tal y como se ha mencionado anteriormente.

En relación al comportamiento del material en un ensayo de relajación frente a diferentes cargas iniciales, fue necesario definir dos curvas, una correspondiente a una aplicación de la carga durante $120 \mathrm{~h}$ y otra durante un año, para poder considerar tiempos de enrollamiento diferentes. Para la obtención de la curva correspondiente a una aplicación de la carga de 120 h se contaba únicamente con los resultados experimentales correspondientes a dos tensiones iniciales ( $70 \%$ y $80 \%$ de la tensión de rotura), el resto de puntos se estimaron en base a los resultados del estudio realizado por Atienza y Elices (15).

Por otra parte, la normativa (3) proporciona expresiones que permiten estimar las pérdidas por relajación a diferentes edades a partir de un dato inicial. En el artículo 38 de la EHE-08 (3) se detalla la evolución de la relajación con el tiempo en las primeras $1.000 \mathrm{~h}$ de aplicación de la carga, lo cual permite obtener la relajación a $1.000 \mathrm{~h}$ a partir del valor correspondiente a $120 \mathrm{~h}$. Asimismo, según dicho artículo, se puede obtener la relajación a 1 año partiendo del valor a $1.000 \mathrm{~h}$ empleando la siguiente expresión [1]:

\subsection{Prediction of stress relaxation losses on wires coiled for a long-term period}

The model described above is used to predict the relaxation losses on the wires tested experimentally. For this, the experimentally obtained stress-strain curve is used (Figure 3), as well as the residual stresses measured on the wire perimeter and on the wire diameter, as described before.

In order to describe the relaxation behaviour of the material under different initial loadings, two diagrams are defined: one corresponds to a $120 \mathrm{~h}$ test and the other to a one-year-long test, so that different coiling periods can be considered. To obtain the diagram corresponding to a $120 \mathrm{~h}$ test, two results are available; one for an initial load of 0.70 uts and another one for an initial load of 0.80 uts. The rest of the diagram is estimated and based on the work by Atienza and Elices (15).

On another note, the Spanish standard (3) gives an expression to estimate the relaxation losses after different time periods. In Article 38 of the Spanish standard EHE-08 (3) the evolution of relaxation losses with time is defined for the first 1000 hours of the test, which can be used to obtain the relaxation losses at $1000 \mathrm{~h}$ using the relaxation losses at $120 \mathrm{~h}$. This Article also gives an expression to obtain the relaxation for a one-year relaxation test by means of the following expression [1]:

$$
\rho_{(t)}=\rho_{1000} \cdot\left(\frac{t}{1000}\right)^{k}
$$


donde:

$\rho_{\mathrm{t}} \quad$ : relajación a t horas

$\rho_{1000}$ : relajación a 1.000 horas

y k, un factor que se obtiene con la expresión [2]:

where:

$\rho_{t} \quad$ : Relaxation after $t$ hours

$\rho_{1000}:$ Relaxation after 1000 hours

and $k$, a factor that can be obtained with the following expression [2]:

$$
k=\log \left(\frac{\rho_{1000}}{\rho_{100}}\right)=\log 1.429
$$

De esta manera, habiendo obtenido la curva correspondiente a $120 \mathrm{~h}$, fue posible obtener la correspondiente a 1 año sin más que aplicar dichas expresiones.

En la Tabla 1 se muestran los resultados de la relajación de tensiones medidas experimentalmente para las probetas con los tres radios de doblado y las dos tensiones de ensayo, y se comparan con los proporcionados por el modelo analítico propuesto.

Los resultados de la relajación de tensiones obtenidos se ajustan bien a los medidos experimentalmente, si bien los sobrestiman ligeramente.

\section{DISCUSIÓN}

El modelo simplificado propuesto predice razonablemente bien la relajación de tensiones generada por el almacenamiento prolongado del alambre enrollado. De esta manera, y considerando válido el modelo propuesto, en este apartado se analiza la influencia de algunos parámetros sobre la relajación final experimentada por un alambre sometido a un enrollamiento prolongado. No se estudia aquí el efecto de la temperatura de almacenamiento, aspecto que puede consultarse en la referencia (10).

El modelo emplea la curva de relajación del material obtenida experimentalmente, en este caso en un ensayo con una duración de 120 horas. Esta curva (Figura 7) corresponde al ajuste obtenido únicamente a partir de 2 puntos (ensayos de relajación al 70 y $80 \%$ de la tensión de rotura del acero con probeta recta). La curva de relajación del material juega un papel importante en
By means of this expression, once the $120 \mathrm{~h}$ test diagram is defined, the one-year-long test diagram can be defined.

In Table 1 the results obtained with the analytical model for the specimens tested are given and compared with the experimental results. As mentioned before, three coiling diameters and two test initial loadings are considered.

The results obtained with the analytical model show good agreement with the measures obtained experimentally, although maybe a little overestimated.

\section{DISCUSSION}

The simplified model that is proposed in this paper predicts reasonably well the stress relaxation losses on wires coiled and stored for a long-term period. Therefore, and considering the model as valid, this section analyses the influence of some parameters on the final relaxation test applied on long-term coiled wires. The influence of storage temperature is not studied here, it can be consulted on the reference (10).

As mentioned before, this model uses the relaxation diagram of the material, in this case obtained experimentally with a $120 \mathrm{~h}$ test. This diagram (Figure 7) corresponds to an adjustment obtained only with two points (tests at 0.70 uts and at 0.80 uts using a wire before coiling). Given that the relaxation diagram plays an important role on the final results, it would seem

Tabla 1 / Table 1

Resultados experimentales y predicciones obtenidas con el modelo analítico de las pérdidas por relajación de los alambres enrolladosa. Relaxation losses for the analysed wires: comparison between the experimental values and the values obtained with the analytical modela

\begin{tabular}{|c|c|c|c|c|}
\hline & \multicolumn{2}{|c|}{ Ensayos / Tests } & \multicolumn{2}{|c|}{ Modelo / Model } \\
\hline & \multicolumn{2}{|c|}{ Pérdidas por relajación / Relaxation losses } & \multicolumn{2}{|c|}{ Pérdidas por relajación / Relaxation losses } \\
\hline Diámetro desenrollado / Diameter uncoiled & \multicolumn{2}{|c|}{$\mathrm{F}=0.70 \mathrm{~F}_{\text {ult }}\left(\Delta \sigma / \sigma_{0}\right) \mathrm{F}=0.80 \mathrm{~F}_{\text {ult }}\left(\Delta \sigma / \sigma_{0}\right)$} & \multicolumn{2}{|c|}{$\mathrm{F}=0.70 \mathrm{~F}_{\text {ult }}\left(\Delta \sigma / \sigma_{0}\right) \mathrm{F}=0.80 \mathrm{~F}_{\text {ult }}\left(\Delta \sigma / \sigma_{0}\right)$} \\
\hline Alambre recto / Straight & $1.80 \%$ & $3.70 \%$ & - & - \\
\hline $\mathrm{D}=9000 \mathrm{~mm}$ & $1.91 \%$ & $4.64 \%$ & $2.34 \%$ & $4.35 \%$ \\
\hline $\mathrm{D}=1000 \mathrm{~mm}$ & $4.04 \%$ & $6.75 \%$ & $4.25 \%$ & $6.73 \%$ \\
\hline $\mathrm{D}=500 \mathrm{~mm}$ & $5.44 \%$ & $6.39 \%$ & $5.96 \%$ & $7.85 \%$ \\
\hline
\end{tabular}

a Las pérdidas se expresan como porcentajes de la carga inicial aplicada. / These losses are expressed as percentages of the initial load. 
los resultados obtenidos, por lo que parece adecuado comprobar la influencia que el ajuste de la curva de relajación tiene en los resultados finales.

Para estudiar este aspecto, se han realizado cálculos para diferentes diámetros de enrollamiento y para cargas iniciales del 70 y del $80 \%$ de la carga de rotura considerando tres curvas de relajación a 120 horas diferentes; las curvas consideradas se muestran en la Figura 9. La curva intermedia corresponde a la obtenida para el material empleado en este trabajo, y cuya obtención se detalló en el apartado 3.3. Las otras dos curvas, una superior y otra inferior, corresponden a dos curvas obtenidas a partir de la intermedia y en las que se ha desplazado ligeramente el tramo donde las pérdidas por relajación experimentan un fuerte incremento.

La Tabla 2 muestra los valores obtenidos con el modelo al incorporar las tres curvas de relajación propuestas en la Figura 9. Se observa la gran influencia que tiene la curva adoptada sobre la relajación final, que puede conducir a variaciones de hasta el $35 \%$ respecto a la adoptada inicialmente. Este aspecto no invalida el modelo propuesto sino que pone de manifiesto la necesidad de contar con datos de relajación de tensiones medidos experimentalmente, a ser posible con varios niveles de tensión (70, 80 y $90 \%$ de la carga de rotura), para obtener una buena predicción del efecto del enrollamiento prolongado en la relajación de tensiones. Hay dos aspectos fundamentales que afectan al fenómeno estudiado: a) el radio de enrollamiento, $y$ b) el tiempo durante el cual el alambre permanece enrollado. Con el fin de estudiar la influencia de estas dos variables se han obtenido, con el modelo propuesto, los resultados del ensayo de relajación de tensiones adoptando las siguientes variables:

- Diámetro del alambre: 5 y 7,5 mm.

- Diámetro de enrollamiento: $500 \mathrm{~mm}, 1.000 \mathrm{~mm}$, $1.500 \mathrm{~mm}, 2.000 \mathrm{~mm}$ y $2.500 \mathrm{~mm}$.

- $\quad$ Sin tensiones residuales iniciales. sensible to check the influence of this adjustment on them.

In order to study this topic, two calculations are performed for different coiling diameters and for initial loadings of 0.70 uts and 0.80 uts, considering three $120 \mathrm{~h}$ test relaxation diagrams; these diagrams are shown in Figure 9. The intermediate one corresponds to the diagram used for the material tested in this study and was obtained in section 3.3. The other two, one of them higher and the other one lower, are obtained by using the intermediate diagram and moving the branch where relaxation losses show a significant increase.

Table 2 shows the results obtained using the analytical model with the three relaxation diagrams considered (Figure 9). According to these results, the shape of the relaxation diagram has a high influence on the final relaxation losses, since these show a variation of up to $35 \%$ compared with the one adopted initially, the intermediate diagram. These results do not mean that the model is not valid, but emphasise how important it is to obtain experimental results of relaxation losses under different initial loadings (especially at 0.70 uts, 0.80 uts and 0.90 uts). Two parameters are of particularly significant influence on the process studied in this paper: a) coiling diameter, and b) coiling time period. To analyse how these parameters affect the final relaxation behaviour of the material, the analytical model is used under different assumptions considering the following scenarios:

- Two wire diameters: 5 and $7.5 \mathrm{~mm}$.

- Five coiling diameters: $500 \mathrm{~mm}, 1000 \mathrm{~mm}, 1500 \mathrm{~mm}$, $2000 \mathrm{~mm}$ and $2500 \mathrm{~mm}$.

- No initial residual stresses.

Tabla 2 / Table 2

Predicción analítica de las pérdidas por relajación para diferentes diámetros de enrollamiento y para las tres curvas de relajación de la Figura 9a. Analytical results of the relaxation losses for different coiling diameters and for each of the three relaxation curves shown in Figure ga.

\begin{tabular}{|c|c|c|c|c|c|c|}
\hline \multirow[b]{2}{*}{$\begin{array}{c}\text { Diámetro } \\
\text { desenrrollado / } \\
\text { Diameter uncoiled }\end{array}$} & \multirow[b]{2}{*}{$\begin{array}{l}\text { Carga inicial / } \\
\text { Initial load }\end{array}$} & \multicolumn{3}{|c|}{ Pérdidas por relajación / Relaxation Losses $\left(\Delta \sigma / \sigma_{0}\right)$} & \multicolumn{2}{|c|}{$\begin{array}{c}\text { Diferencias con la curva intermedia / } \\
\text { Differences with the intermediate } \\
\text { diagram }\end{array}$} \\
\hline & & $\begin{array}{l}\text { Curva superior / } \\
\text { Higher diagram }\end{array}$ & $\begin{array}{l}\text { Curva intermedia / } \\
\text { Intermediate } \\
\text { diagram }\end{array}$ & $\begin{array}{l}\text { Curva inferior / } \\
\text { Lower diagram }\end{array}$ & $\begin{array}{l}\text { Curva superior I } \\
\text { Higher diagram }\end{array}$ & $\begin{array}{l}\text { Curva inferior / } \\
\text { Lower diagram }\end{array}$ \\
\hline \multirow{2}{*}{$\mathrm{D}=9000 \mathrm{~mm}$} & $\mathrm{~F}=0.70$ Fult & $7.2 \%$ & $5.9 \%$ & $4.3 \%$ & $22.0 \%$ & $-27.1 \%$ \\
\hline & $\mathrm{F}=0.80$ Fult & $8.2 \%$ & $7.8 \%$ & $6.0 \%$ & $5.1 \%$ & $-23.1 \%$ \\
\hline \multirow{2}{*}{$\mathrm{D}=1000 \mathrm{~mm}$} & $\mathrm{~F}=0.70$ Fult & $5.1 \%$ & $4.2 \%$ & $3.1 \%$ & $21.4 \%$ & $-26.2 \%$ \\
\hline & $\mathrm{F}=0.80$ Fult & $8.0 \%$ & $6.7 \%$ & $4.8 \%$ & $19.4 \%$ & $-28.4 \%$ \\
\hline \multirow{2}{*}{$\mathrm{D}=500 \mathrm{~mm}$} & $\mathrm{~F}=0.70$ Fult & $3.1 \%$ & $2.3 \%$ & $1.9 \%$ & $34.8 \%$ & $-17.4 \%$ \\
\hline & $\mathrm{F}=0.80$ Fult & $5.9 \%$ & $4.4 \%$ & $3.0 \%$ & $34.1 \%$ & $-31.8 \%$ \\
\hline
\end{tabular}

a Las pérdidas se expresan como porcentajes de la carga inicial aplicada / These losses are expressed as percentages of the initial load. 


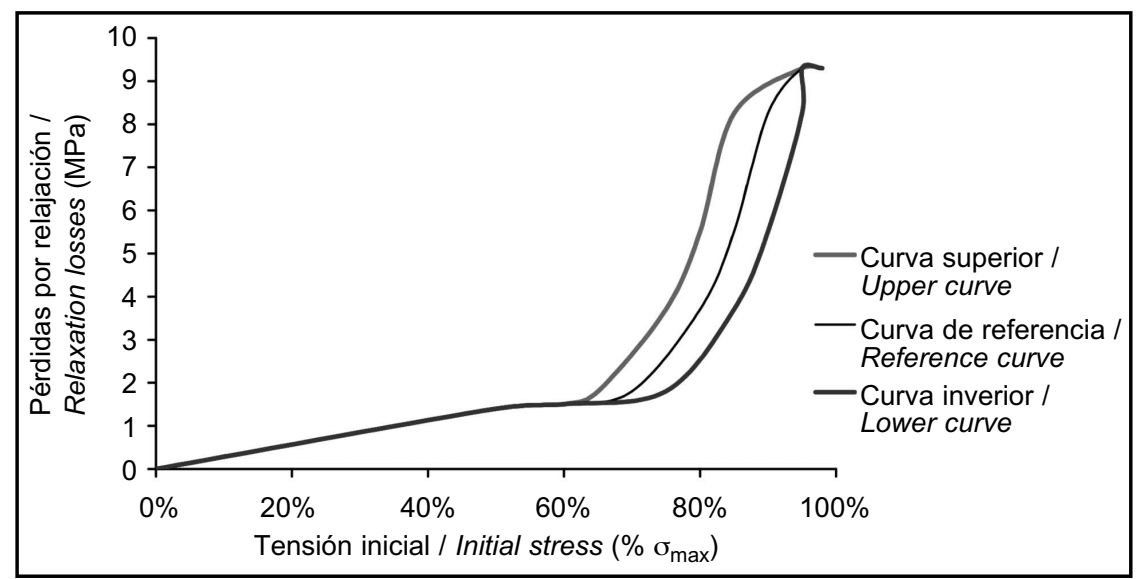

Figura 9. Curvas de relajación empleadas en el estudio de sensibilidad de esta curva sobre la relajación final. Figure 9. Relaxation diagrams used in sensitivity study of the curve on the final relaxation losses.

- Tiempo de enrollamiento: desenrollamiento instantáneo, tras un almacenamiento de 120 horas y tras un almacenamiento de 1 año.

- Fuerza a la que se realiza en ensayo de relajación de tensiones: $70 \%$ y $80 \%$ de la tensión de rotura del alambre.

- Ensayo de relajación a $120 \mathrm{~h}$.

El tiempo de enrollamiento de 120 horas puede parecer escaso, pero se debe tener en cuenta que la mayor parte de la relajación de tensiones se desarrolla en las primeras horas en las que el acero está tensionado.

Las Tablas 3 y 4 muestran los resultados de relajación de tensiones correspondientes a la combinación de las variables enumeradas para los alambres de diámetro 7,5 mm y $5 \mathrm{~mm}$, respectivamente. Se puede observar que la influencia del diámetro de enrollado solo es apreciable en el diámetro menor, correspondiente a 500 mm. Este diámetro es inferior a los admitidos por la norma (3) tanto en el
- Three coiling time periods: instant uncoiling, uncoiling after $120 \mathrm{~h}$ and uncoiling after one year.

- Two initial loadings in the relaxation test: 0.70 uts and 0.80 uts.

- A 120 h relaxation test.

Although a $120 \mathrm{~h}$ coiling time period may seem to be short, it must be considered that most of the relaxation losses are developed within the first hours of this period.

The results of this study can be consulted in Tables 3 and 4 that show the results for $7.5 \mathrm{~mm}$ diameter wires and 5.0 $\mathrm{mm}$ diameter wires, respectively. These results show that the influence of the coiling diameter is only noticeable in the results of the smaller coiling diameter, equal to $500 \mathrm{~mm}$. This diameter is smaller than those permitted by the standard (3), not only for $7.5 \mathrm{~mm}$-diameter wires, but also

Tabla 3 / Table 3

Influencia del diámetro de enrollamiento y del tiempo de almacenamiento sobre las pérdidas de relajación en un alambre de diámetro $7,5 \mathrm{~mm}$ sin tensiones residuales iniciales para un ensayo de relajación a $120 \mathrm{~h}^{\mathrm{a}}$.

Influence of the coiling diameter and the time of storage on relaxation losses for a $7.5 \mathrm{~mm}$-diameter wire without initial residual stresses in a $120 \mathrm{~h}$ relaxation testa.

\begin{tabular}{|c|c|c|c|c|c|c|}
\hline & \multicolumn{5}{|c|}{ Pérdidas en un alambre de $\phi=7,5 \mathrm{~mm} /$ Relaxation losses in a wire of $\phi=7.5 \mathrm{~mm}$} \\
\cline { 2 - 7 } & \multicolumn{2}{|c|}{$\begin{array}{c}\text { Pérdidas por relajación / Relaxation losses } \\
\left(\Delta \sigma / \mathbf{\sigma}_{0}\right) \mathrm{F}=\mathbf{0 . 7 0} \mathrm{F}_{\text {ult }}\end{array}$} & \multicolumn{3}{|c|}{$\begin{array}{c}\text { Pérdidas por relajación / Relaxation losses } \\
\left(\Delta \sigma / \sigma_{0}\right) \mathrm{F}=\mathbf{0 . 8 0} \mathrm{F}_{\text {ult }}\end{array}$} \\
\hline $\begin{array}{c}\text { Diámetro de } \\
\text { enrollado / Coiling } \\
\text { diameter }\end{array}$ & $\begin{array}{c}\text { Sin } \\
\text { almacenamiento / } \\
\text { No storage }\end{array}$ & $\begin{array}{c}\text { Almacenado } \\
\text { durante } \\
\mathbf{1 2 0} \mathbf{h} / \mathbf{1 2 0} \boldsymbol{h} \\
\text { storage }\end{array}$ & $\begin{array}{c}\text { Almacenado } \\
\text { durante un año / } \\
\text { One-year storage }\end{array}$ & $\begin{array}{c}\text { Sin } \\
\text { almacenamiento / } \\
\text { No storage }\end{array}$ & $\begin{array}{c}\text { Almacenado } \\
\text { durante } \\
\mathbf{1 2 0} \mathbf{h} / \mathbf{1 2 0} \boldsymbol{h} \\
\text { storage }\end{array}$ & $\begin{array}{c}\text { Almacenado } \\
\text { durante un año / } \\
\text { One-year storage }\end{array}$ \\
\hline $\mathrm{D}=500 \mathrm{~mm}$ & $2.71 \%$ & $3.04 \%$ & $3.36 \%$ & $4.70 \%$ & $5.09 \%$ & $5.47 \%$ \\
\hline $\mathrm{D}=1000 \mathrm{~mm}$ & $1.81 \%$ & $1.85 \%$ & $1.88 \%$ & $3.73 \%$ & $3.77 \%$ & $3.80 \%$ \\
\hline $\mathrm{D}=1500 \mathrm{~mm}$ & $1.81 \%$ & $1.85 \%$ & $1.86 \%$ & $3.73 \%$ & $3.76 \%$ & $3.78 \%$ \\
\hline $\mathrm{D}=2000 \mathrm{~mm}$ & $1.81 \%$ & $1.83 \%$ & $1.84 \%$ & $3.73 \%$ & $3.75 \%$ & $3.76 \%$ \\
\hline $\mathrm{D}=2500 \mathrm{~mm}$ & $1.81 \%$ & $1.83 \%$ & $1.83 \%$ & $3.73 \%$ & $3.74 \%$ & $3.75 \%$ \\
\hline
\end{tabular}

a Las pérdidas se expresan como porcentajes de la carga inicial aplicada. / These losses are expressed as percentages of the initial load. 
Tabla 4 / Table 4

Influencia del diámetro de enrollamiento y del tiempo de almacenamiento sobre las pérdidas de relajación en un alambre de diámetro $5,0 \mathrm{~mm}$ sin tensiones residuales iniciales para un ensayo de relajación a 120 ha.

Influence of the coiling diameter and the time of storage on relaxation losses for a 5.0 mm-diameter wire without initial residual stresses in a 120 h relaxation testa.

\begin{tabular}{|c|c|c|c|c|c|c|}
\hline \multirow[b]{3}{*}{$\begin{array}{c}\text { Diámetro de } \\
\text { enrollado / Coiling } \\
\text { diameter }\end{array}$} & \multicolumn{6}{|c|}{ Pérdidas en un alambre de $\phi=5,0 \mathrm{~mm} /$ Relaxation losses in a wire of $\phi=5.0 \mathrm{~mm}$} \\
\hline & \multicolumn{3}{|c|}{$\begin{array}{l}\text { Pérdidas por relajación / Relaxation losses } \\
\qquad\left(\Delta \sigma / \sigma_{0}\right) \mathrm{F}=0.70 \mathrm{~F}_{\mathrm{ult}}\end{array}$} & \multicolumn{3}{|c|}{$\begin{array}{l}\text { Pérdidas por relajación / Relaxation losses } \\
\qquad\left(\Delta \sigma / \sigma_{0}\right) \mathrm{F}=0.80 \mathrm{~F}_{\mathrm{ult}}\end{array}$} \\
\hline & $\begin{array}{c}\text { Sin } \\
\text { almacenamiento / } \\
\text { No storage }\end{array}$ & $\begin{array}{c}\text { Almacenado } \\
\text { durante } \\
120 \mathrm{~h} / 120 \mathrm{~h} \\
\text { storage }\end{array}$ & $\begin{array}{c}\text { Almacenado } \\
\text { durante un año / } \\
\text { One-year } \\
\text { storage }\end{array}$ & $\begin{array}{c}\text { Sin } \\
\text { almacenamiento / } \\
\text { No storage }\end{array}$ & $\begin{array}{l}\text { Almacenado } \\
\text { durante } 120 \mathrm{~h} / \\
120 \mathrm{~h} \text { storage }\end{array}$ & $\begin{array}{c}\text { Almacenado } \\
\text { durante un año / } \\
\text { One-year } \\
\text { storage }\end{array}$ \\
\hline $\mathrm{D}=500 \mathrm{~mm}$ & $1.85 \%$ & $1.93 \%$ & $2.07 \%$ & $3.78 \%$ & $3.88 \%$ & $4.01 \%$ \\
\hline $\mathrm{D}=1000 \mathrm{~mm}$ & $1.81 \%$ & $1.85 \%$ & $1.86 \%$ & $3.73 \%$ & $3.76 \%$ & $3.78 \%$ \\
\hline $\mathrm{D}=1500 \mathrm{~mm}$ & $1.81 \%$ & $1.83 \%$ & $1.83 \%$ & $3.73 \%$ & $3.74 \%$ & $3.75 \%$ \\
\hline $\mathrm{D}=2000 \mathrm{~mm}$ & $1.81 \%$ & $1.82 \%$ & $1.82 \%$ & $3.73 \%$ & $3.74 \%$ & $3.74 \%$ \\
\hline $\mathrm{D}=2500 \mathrm{~mm}$ & $1.81 \%$ & $1.82 \%$ & $1.82 \%$ & $3.73 \%$ & $3.74 \%$ & $3.74 \%$ \\
\hline
\end{tabular}

a Las pérdidas se expresan como porcentajes de la carga inicial aplicada. / These losses are expressed as percentages of the initial load.

caso del cable de 7,5 mm como en el de $5 \mathrm{~mm}$. De la misma manera, se observa cómo la influencia de un tiempo de almacenamiento elevado solo es apreciable en el diámetro menor, siendo prácticamente nula en el resto.

Estos resultados corroboran la adecuación de la normativa al establecer un diámetro mínimo de enrollado de los alambres y cordones para aceros de pretensar de baja relajación. Este diámetro mínimo es superior al necesario para evitar la plastificación del alambre o cordón al enrollarlo y se establece para evitar una deformación remanente excesiva en el material al desenrollarlo. De hecho, y como se ha indicado en la introducción, algunas normas (3) limitan la flecha admisible a $25 \mathrm{~mm}$ en alambres y $20 \mathrm{~mm}$ en cordones en una base de medida de $1 \mathrm{~m}$, al dejarlos sobre una superficie plana una vez desenrollados, aspecto que pone en evidencia la potencial existencia de este problema.

Los resultados experimentales presentados y los cálculos realizados con el modelo propuesto ayudan a entender el proceso y cuantificar las deformaciones remanentes observadas en los alambres de pretensar comerciales desenrollados cuando han permanecido enrollados durante largos periodos de tiempo. Los resultados obtenidos indican que la curvatura remanente se debe a que durante el tiempo que el alambre ha estado enrollado, aunque no haya alcanzado las tensiones de plastificación, las tensiones provocadas por el enrollado pueden ser suficientes para que la sección transversal experimente una relajación tensiones de valor variable en la dirección radial del enrollamiento, generando unas deformaciones permanentes al desenrollarse $y$, por tanto, unas tensiones residuales asociadas. for $5.0 \mathrm{~mm}$-diameter wires. In addition to this, the influence of a long-term coiling period is again only noticeable in the results of the smaller coiling diameter, with it being almost negligible in the others.

These results confirm the importance of limiting the minimum diameter allowed for low-relaxation prestressing steel wires and strands. This minimum diameter is greater than that needed to avoid plastic deformation of the material and is defined to avoid an excessively high remaining curvature when it is uncoiled. In fact, as mentioned in the introduction, some standards (3) limit the sagitta on a $1 \mathrm{~m}$-long wire after uncoiling, so that it is $25 \mathrm{~mm}$ for wires and $20 \mathrm{~mm}$ for strands, when uncoiled and placed over a plane surface. This evidences the potential occurrence of this problem.

The experimental results presented in this paper, as well as the calculations carried out with the proposed analytical model, help to understand the process and quantify the remaining curvature observed on commercial prestressing steel wires once they have been uncoiled after a long-term coiling period. These results show that the remaining curvature is the consequence of local relaxation losses developed during the coiling period. Although the material is always in the elastic regime, some parts of the cross section may be under high elastic stress, high enough to develop relaxation losses, with them being variable along the radial direction of the coil, giving rise to permanent deformations when the wire is uncoiled and, therefore, leading to additional residual stresses. 


\section{CONCLUSIONES}

En este trabajo se ha estudiado el efecto que el diámetro de enrollamiento y el tiempo de almacenamiento del acero de pretensar pueden tener sobre su comportamiento en el ensayo de relajación de tensiones.

Los ensayos realizados han mostrado que diámetros de enrollado pequeños, aunque no conduzcan a la plastificación del alambre, aumentan las pérdidas por relajación tras un periodo prolongado de almacenamiento.

El modelo analítico propuesto ha permitido cuantificar la distribución de las tensiones en la sección transversal del alambre a lo largo del proceso de enrollamiento, almacenamiento, desenrollamiento y realización del ensayo de relajación de tensiones.

El modelo ha permitido estudiar y confirmar la influencia de las tensiones residuales iniciales del alambre en todo el proceso, y particularmente en los resultados del ensayo de relajación de tensiones tras el almacenamiento prolongado del rollo de alambre.

En la práctica se presta una gran atención al estado del material tras su fabricación, olvidando lo que pueda ocurrir desde ese instante hasta su puesta en obra, es decir, durante el tiempo que este permanece enrollado y almacenado. Si bien es cierto que del presente estudio se puede concluir que respetando los límites establecidos en la norma este efecto puede ser despreciado, en opinión de los autores, es recomendable realizar la comprobación de la curvatura del alambre antes de su puesta en carga, tal y como requieren algunas normas, pues esta curvatura refleja la importancia de las tensiones residuales almacenadas en el alambre independientemente de su origen.

\section{AGRADECIMIENTOS}

Los autores agradecen al Ministerio de Economía y Competitividad la financiación proporcionada a través de las ayudas DPI2011-24876 y IPT-42000-2010-31, respectivamente. F. Suárez, además, agradece a la Fundación Agustín de Betancourt la financiación proporcionada a través de una beca de investigación. Asimismo, los autores agradecen a Luisa Villares y Luis del Pozo, de EMESA Trefilerías, su inestimable ayuda y consejo.

\section{CONCLUSIONS}

In this paper, the effect of the coiling diameter and the coiling time period on the relaxation behaviour of prestressing steel wires has been studied.

Tests carried out in this study have shown that the use of small coiling diameters increases the relaxation losses for long-term periods of storage, even if it does not induce plastic strains on the material.

The proposed analytical model has helped to quantify the stress distribution in the cross section of the wire throughout the coiling-storing-uncoiling process and after the eventual relaxation test.

Such a model has also helped to study and confirm the influence of the initial residual stresses profile of the wire on the whole process, especially on the results of the relaxation test carried out after a long-term coiling period.

In practice, a significant degree of attention is paid to the material properties throughout the manufacturing process, and little to what happens after it, that is to say, during the storage period. The material is stored in coils and, therefore, a bending moment is applied over the cross section as long as the wire is stored. Although the results obtained in this work show that if the requirements of standards are met, the effect of coiling can be neglected. In the authors' opinion it is recommended that the remaining curvature of the wire be checked before it is accepted by the client, following the requirements of some standards, since it is a consequence of the residual stresses of the wire, no matter what their origin is.

\section{ACKNOWLEDGEMENTS}

The authors gratefully acknowledge the financial support for the research provided by the Spanish Ministerio de Economía y Competitividad under grants DPI2011-24876 and IPT-42000-2010-31. They also express their gratitude to Luis del Pozo and Luisa Villares, from Emesa Trefilería S.A. (Arteixo, La Coruña) for their invaluable help and advice. Finally, F. Suarez also wishes to express his gratitude to the Fundación Agustín de Bethancourt for the grant provided. 


\section{BIBLIOGRAFÍA / BIBLIOGRAPHY}

(1) EN ISO 15630-3 (2010): "Steel for the reinforcement and prestressing of concrete - Test methods".

(2) ASTM E328-86 e1: "Standard Test Methods for Stress Relaxation Tests for Materials and Structures" (1996).

(3) EHE-08. Instrucción de Hormigón Estructural. Publicaciones del Ministerio de Fomento. Secretaría General Técnica.

(4) Elices, M.: "Influence of residual stresses in the performance of cold-drawn pearlitic wires". Journal of Materials Science, vol. 39, no 12 (2004), pp. 3889-3899. http://dx.doi.org/10.1023/B:JMSC.0000031470.31354.b5

(5) Atienza, J. M.; Elices, M.: "Influence of residual stresses in the stress relaxation of cold drawn wires", Materials and Structures, vol. 37 (2004), pp. 301-304.

(6) Sánchez-Gálvez, V.; Elices, M.; Astiz M.A.: "A new formula for stress relaxation in steels". Materials and Structures, vol. 9, nº 54 (1976), pp. 411-417.

(7) Sánchez-Gálvez, V.; Elices, M.: "The relationship between tensile strain, creep and stress relaxation in cold-drawn steels at low temperatures". Materials Science and Engineering, no 78 (1986), pp. 1-8.

(8) Etienne, C. F.; Van't Spijker, F.: "The influence of prestretching on the relaxation properties of cold drawn wire for prestressed concrete". Cement (1967).

(9) Magura, D.: Sozen, M.; Siess, Ch.: "A study of stress relaxation in prestressing reinforcement". PCI Journal (1964), pp. 13-57.

(10) Elices, M.; Suárez, F.; Gálvez, J. C.; Cendón, D. A.; Atienza, J. M.: "Influence of coiling on the stress relaxation of prestressing steel wires", Structural Concrete, vol. 12, no 2 (2011), pp. 120-125.

(11) Fib. Bulletin 55. Model code 2010. First complete draft, vol. 1. Section 5.3.6, pp. 187-190.

(12) Ruiz-Hervías, J.; Atienza, J. M.; Elices, M.; Oliver, E. C.; "Optimisation of post-drawing treatments by means of neutron diffraction", Materials Science and Engineering A, vol. 480, no 1-2 (2008), pp. 439-448. http://dx.doi.org/10.1016/j.msea.2007.07.017

(13) Atienza, J. M.; Ruiz-Hervías, J.; Martínez-Pérez, M. L.; Mompeán, F. J.; García-Hernández, M.; Elices, M.: "Residual stresses in cold drawn pearlitic rods". Scripta Materialia, vol. 52 (2005), pp. 1223-1228. http://dx.doi.org/10.1016/j.scriptamat.2005.03.003

(14) Martínez-Pérez, M. L. et al.: "Residual stress profiling in the ferrite and cementite phases of cold-drawn steel rods by synchrotron X-ray and neutron diffraction". Acta Materialia, vol. 52 (2004), pp. 5303-5313. http://dx.doi.org/10.1016/j.actamat.2004.07.036

(15) Atienza, J. M.; Elices, M.: "Role of residual stresses in the stress relaxation of prestressed concrete wires". Journal of Materials in Civil Engineering, 19: 8 (2007), pp. 703-707. 